\title{
Histopathological changes in kidney, Adrenal gland and Skin due to the Effect of Captopril in Mice
}

\author{
H.A. N.AL-Zaiydi \\ S. K.Majeed \\ Coll. of Vet. Med./Univ. of Al-Qadysia Coll. of Vet. Med./ Univ.of Al-Basrah
}

\section{Abstract}

The present study project was on toxic pathology of captopril (antihypertension drug). The study was done on 44 white mice of 1-1.5 months old (males and females), the mice were divided into four equal groups of 10 mice ( 5 of each sex), for 6 months. The groups included: untreated control, low therapeutic dose $(2.1 \mathrm{mg} / \mathrm{kg})$, intermediate dose $(6.3 \mathrm{mg} / \mathrm{kg}$ ) and high dose (toxic) $18.9 \mathrm{mg} / \mathrm{kg}$, daily for 6 months . In addition a peracute high toxicity group treated at $56.7 \mathrm{mg} / \mathrm{kg}$ day, dosage level for two weeks (2 males and 2 females). Histopathological examination showed that captopril affected certain visceral organs as target organs, such as kidney which showed dilated cortical tubules, adrenal gland with evidence of reduced size of medulla and angioedema of the lip region and areas of thickened epidermal layer.

\section{Introduction}

Hypertension has been called the silent killer for many years. It is estimated that one in four adults in the United States have hypertension(1). High blood pressure is a serious health problem, increases the risk of heart attacks, stroke and kidney failure (2).Elevated arterial pressure causes pathological changes in the vasculature and hypertension is the principle cause of stroke, led to disease of coronary arteries with a major contribution to cardiac failure, renal insufficiency and dissecting aneurysm of the aorta (3). The renin-angiotensin system plays a critical role in the regulation of blood pressure and volume homeostasis in mammals. The main effector of the reninangiotensin system is the octapeptide hormone angiotensin II produced by the successive enzymatic cleavage of the hepatic glycoprotein angiotensinogen by kidney derived rennin which secreted from jxttaglomerular cell and angiotensin converting enzyme (ACE) (4).Inhibition of ACE by captopril lowers systemic vascular resistance (5).Goodman \& Gilman (1996), reported that in human subjects with hypertension, ACE inhibitors commonly lower blood pressure. So (ACE) inhibitors alone normalize blood pressure in approximately $50 \%$ of patients with mild to moderate hypertension and many consider (ACE) inhibitors first line drugs for the treatment of high blood pressure.The goal of antihypertensive therapy is not just to lower blood pressure but, more importantly to protect the patients overall risk of cardiovascular disease, because of the effect of capoten (Captopril) the first (ACE) inhibitor on remodeling, it is possible that they will reduce the incidence of heart disease in hypertensive patients more than with other antihypertensive agents (3). This study was designed to have the knowledge of any hidden effect of toxicity of captopril (antihypertensive agent) on organs in white mice, (such as kidney, adrenal gland and skin) in 6 months study in white mice and histopathological studies of these viscera were intended.

\section{Experimental Design:}

Forty fore mice (22 males and 22 females) about 1-1.5 months old, were divided into 4 equal groups (each group

\section{Materials and Methods}

consisted of 5 males and 5 females). The first is control group received only distilled water in dose $0.2 \mathrm{ml}$ by stomach tube daily. Second group as a therapeutic (low dose) 
received $2.1 \mathrm{mg} / \mathrm{kg}$ body weight captopril by stomach tube daily. Third group as intermediate dose received $(6.3 \mathrm{mg} / \mathrm{kg}$ of body weight) captopril by stomach tube daily. Fourth group as a toxic dose (high dose) received $18.9 \mathrm{mg} / \mathrm{kg}$ of body weight, captopril by stomach tube daily (7).Also there was another group called per acute (extra toxic group) consist of ( 2 males and 2 females) administered $56.7 \mathrm{mg} / \mathrm{kg}$ of body weight for 2 weeks. The animals were housed in $6 \times 4 \times 3 \mathrm{~m}^{3}$ room under 12 hour light / 12 hours dark at $21 \pm 4^{\circ} \mathrm{C}$ and put as 5 mice in each standard plastic cages:For histopathology, pieces of (1) $\mathrm{cm}^{3}$ were taken from kidney, adrenal gland and skin, they kept in $10 \%$ neutral buffered formalin for fixation, processed routinely in Histokinette, cut at $5 \mu \mathrm{m}$ thickness by microtome (Jung4291, West Germany) and stained with
Haematoxylin and Eosin stain then examined under light microscope (6).

\section{Treatment:}

Captopril used in the experiment is (Aceprotin) $^{\mathrm{R}}$ as a clear yellowish tablet, each tablet contains $50 \mathrm{mg}$ captopril. It is manufactured by Cyprus (Europe). Each tablet which contains captopril $50 \mathrm{mg}$ diluted with $238 \mathrm{ml}$ distilled water and the mixture was given orally to the treated animals. The administrations was daily and last six months,untreated controls received administration of distilled water only, the same quantity as the treated dose.

\section{Dose Calculation:}

The low (therapeutic) dose of captopril is $2.1 \mathrm{mg} / \mathrm{kg}$ daily, in human with average body weight of $70 \mathrm{~kg}$ (7), so for the mice with average body weight about $25 \mathrm{gm}$ the dose will be $0.25 \mathrm{ml}$ of captopril .

\section{1- Macroscopic Findings: Group A (Control Group):}

There were no significant macroscopic finding; all animals of control group were within normal limits.

\section{Group B: (low dose animals):}

The kidneys (which were considered as a target organ for captopril as reported by (10) ). They were congested in the treated groups, some animals showed enlarged kidneys. Adrenal glands were of normal appearance.

Group C: (intermediate Dose):

The kidney in the intermediate dose group appeared affected; they were enlarged in size and congested. The skin showed to be affected in the intermediate dose as there was stiffness and standing up of the hairs (piloerection). Also there was angioedema which appear clearly in lips of mice.

\section{Group D: (Toxic dose):}

In the present group, The kidney which is considered as a target organ as reported by (10), there were obvious changes including increase in size and congestion. Adrenal gland was reduced in size. All animals in the present group were emaciated and with

\section{Results}

angioedema (which is considered as a characteristic sign for captopril toxicity) which was found in lips and tongue(as in figure 1).

\section{Group E (Peracute Group): (Extratoxic Dose):}

The kidney appeared grey in color and enlarged in size. The adrenal glands were reduced in size. There was angioedema in lips and the skin showing stiffens and stand up of hairs (Piloerection).

\section{2-Microscopic Finding:}

Group A (Control Group) :

There were no significant microscopic findings in control untreated animals.

Group B: (low dose):

The kidney (target organ) contained areas of cortical tubular basophilia with infiltration of lymphocytes and congested glomeruli (as in Figure 2).

\section{Group C: (Intermediate Dose):}

The kidney showed cortical areas of dilated tubules, cortical foci of infiltration of lymphocytes and cortical area of tubular basophiliea was also present (as in Figures 3 and 4).The skin was with numerous hair follicles ,hyperkeratosis thickening of 
epithelium and hypertrophy of epidermis (as in Figure 5 ).

\section{Group D: (Toxic dose):}

There were major changes which occurred in the animals of the present group in all examined organs:

The kidneys were with areas of cortical tubular basophilia, with congestion and infiltration of lymphocyte (as in Figures 6, 7 and 8), also there was severe dilatation of renal cortical tubules, and focal compression of capsules.

The skin was with numerous hair follicles, prominent hyperkeratosis and hypertrophy of epidermis (as in Figure 9), thickening of epithelium, edema and fibrosis in case of

\section{Discussion}

For those reasons and others, this study had focused on the target organ in white mice. Indeed, in this study the animals of all treated groups showed clinical signs, such as rapid loss of body weight which were considered very important clinical signs for captopril toxicity, the causes of these signs were decrease of food consumption (loss of appetite).Most important macroscopic pathological findings which were seen in all treated animals especially animals at high (toxic) level which showed loss of elasticity of the skin due to hyperkeratosis which lead to stiffness and hardness of the skin and piloerection (9).The kidneys are important organs in the body because the function of the kidneys is to maintain the volume and proper composition of the extracellular fluid. When plasma volume is decreased, mean arterial pressure drops and the body compensates by vasoconstriction of blood vessels, resulting in decreased oxygen perfusion. When the volume of plasma is expanded, preload increases as does the blood pressure. The balance between aldosterone and sodium determines the extracellular volume (10).In the present study, the result showed cortical area of dilated tubules in all treated groups in both males and females. That was may be due to exposure of the kidney to antidiuretic angioedema (as in figure10). Adrenal gland showed evidence of reduced size of medulla (as in figure 11).

Group E (Peracute Group): (Extratoxic Dose):

In the present group there were severe damages in the kidney. The kidney showed severe dilatation of renal cortical tubules (as in Figure 12), also there was infiltration of inflammatory cells.

The skin also affected in the present group there was reduced numbers of hair follicles also there was thickening of epithelium of epidermis with hyperkeratosis and hypertrophy of epidermis (as in Figure 13). hormone as a result of secretion of renin and angiotensin by the kidney, aldosterone by the adrenal gland. Those hormones are secreted in an attempt to retain fluid and restore the blood volume, but by inducing vasoconstriction they would increased renal damage.This agrees with (11), who reported that captopril treatment for long time causes the nephrotic syndrome which is due to glomerular dysfunction and marked by heavy proteinurea. In such cases at post mortem the kidney was enlarged, pale and swollen. That was due to dilated, degenerated or necrotic tubules. That agreed with(12), they indicated that kidney weight was increased dose - dependently in both sexes. In addition, the kidneys showed cortical areas of tubular basophilia (regeneration process) associated with a predominant lymphatic infiltration. That indicated regeneration and new formation of cortical tubules replacing degenerating tubules, the above change mostly occur in proximal convoluting tubules, as those tubules they were the most affected in any toxic change on kidney.The infiltration of lymphocytes was a protective effect to any damage in renal tissue. That was supported by the result of (13), they reported that the intrarenal arteries exhibit vascular hyperplasia associated with a perivascular 
inflammatory cells infiltrate.The results of histopathological examination showed severe congestion in blood vessels in kidney. This could be due to the peripheral effect of drug to block the acytyl choline and alph-one receptors which are present on the surface of smooth muscles of blood vessels and presynaptic alpha II receptors, this blocker lead to increase norepinephrein concentration which work on beta receptors, those also present on surface of smooth muscles of blood vessels lead to relaxation of those muscles. This could be due to the effect of the drug on blocking serotonine $\left(5 \mathrm{HT}_{1}\right)$ receptors presynaptic which lead to increase concentration of serotonine and its action on serotonin receptors on postsynapse, which are present on surface of smooth muscle resulting in relaxation of blood vessels and could cause severe hypotension (3).The adrenal gland: The results of the present study showed evidence of reduced size of medulla in high toxic group in both males and females. The above reduction of adrenal medulla could be due to antihypertensive effect of captopril, in which the plasma aldosterone concentration is significantly lowered. The suppressive effects of captopril were completely reserved by chronic treatment with captopril, those findings confirm the view that the renin angiotensin system is involved the maintenance of the growth and steroidogenic capacity of the normal adrenal cortex. (14).Skin: The result showed in lips dilated hair follicles in dermis, minimal edema, fibrosis and thickening of epiderms in high toxic group in both males and females (angioedema). That could be due to the interaction of the drug with hormones regulating the vascular resistance such as the kallikrein -kinin system and the prostaglandin system. The hormone prevents reabsorption of sodium and therefore increases water execration. This result was supported by(15), they concluded from their study that angioedema, an uncommon complication of (ACE) inhibitor therapy is being encountered with increasing frequency, since (ACE) inhibitor causing angioedema predominantly involve the face, lips and oral cavity.

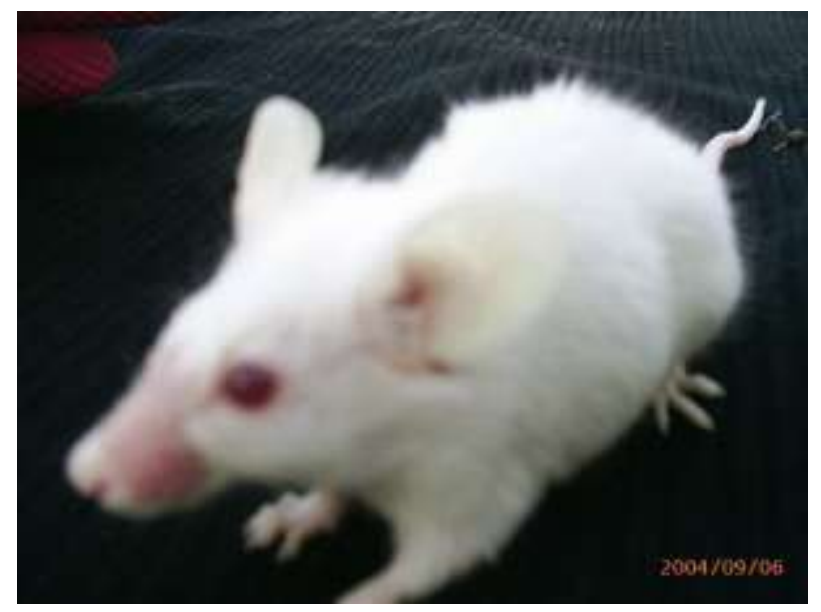

Figure 1: Angioedema characterized by swelling and hyperemia. (high toxic group) 


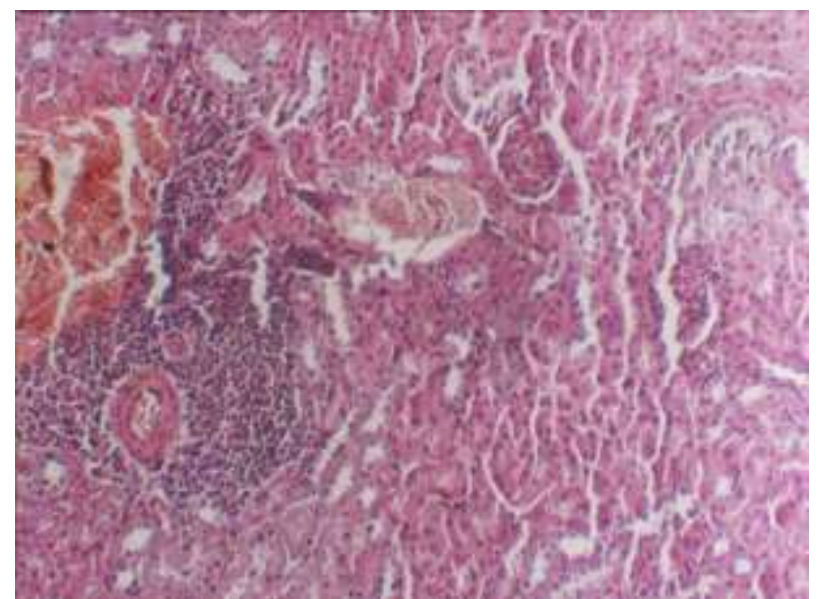

Figure 2: Kidney (low dose group), show perivascular aggregate of lymphocyte in cortex. (X 100 $\mathrm{H} \& \mathrm{E})$.

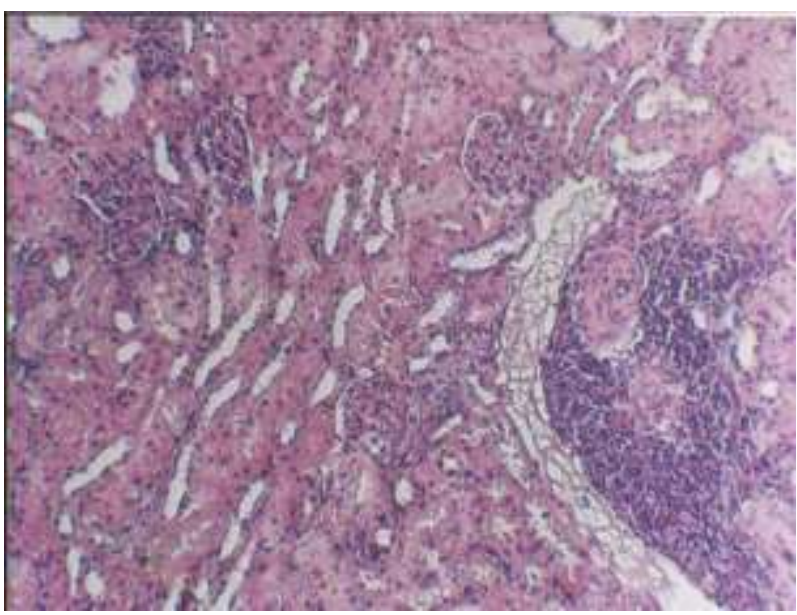

Figure 3: Kidney (intermediate dose group), area of dilated renal cortical tubules and aggregate of lymphocyte. (X 100 H \& E).

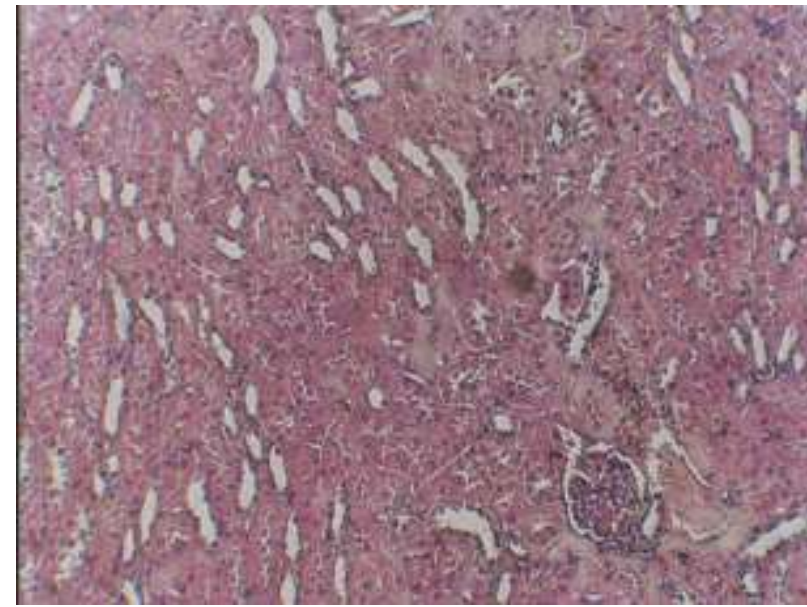

Figure 4: Kidney (intermediate dose group), diffuse dilation of renal cortical tubule. (X $100 \mathrm{H} \&$ E). 


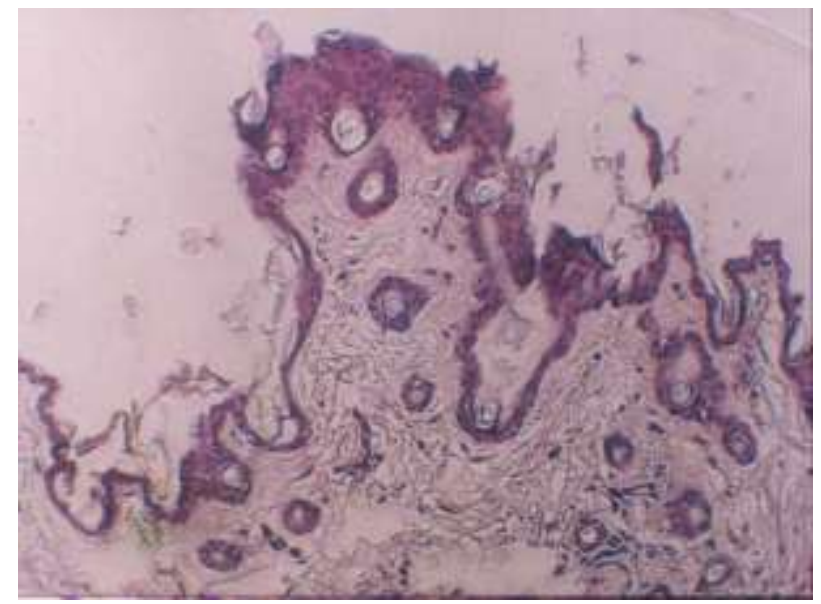

Figure 5: Skin (intermediate dose group), focal thickening and hyperplasia of epidermal cells. (X $50 \mathrm{H} \& \mathrm{E})$.

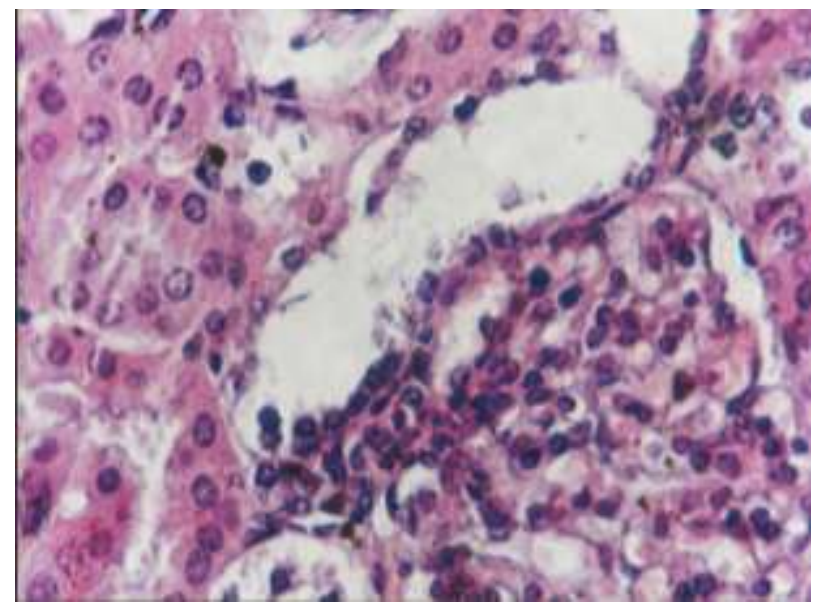

Figure 6: Kidney (toxic dose group), an area of renal cortical tubular basophilia associated with mononuclear cell. (X $100 \mathrm{H}$ \& E).

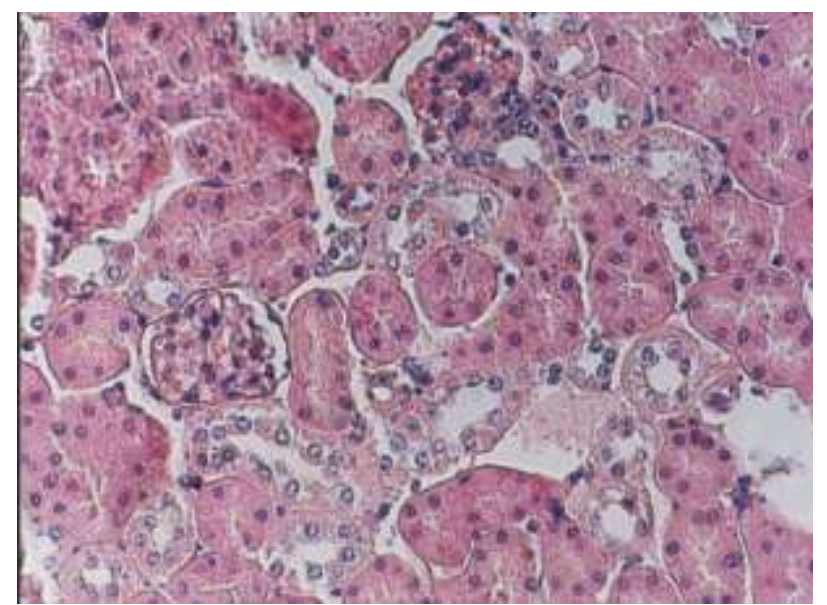

Figure 7: Kidney (toxic dose group), renal cortical area tubular basophilia. (X 100 H \& E). 


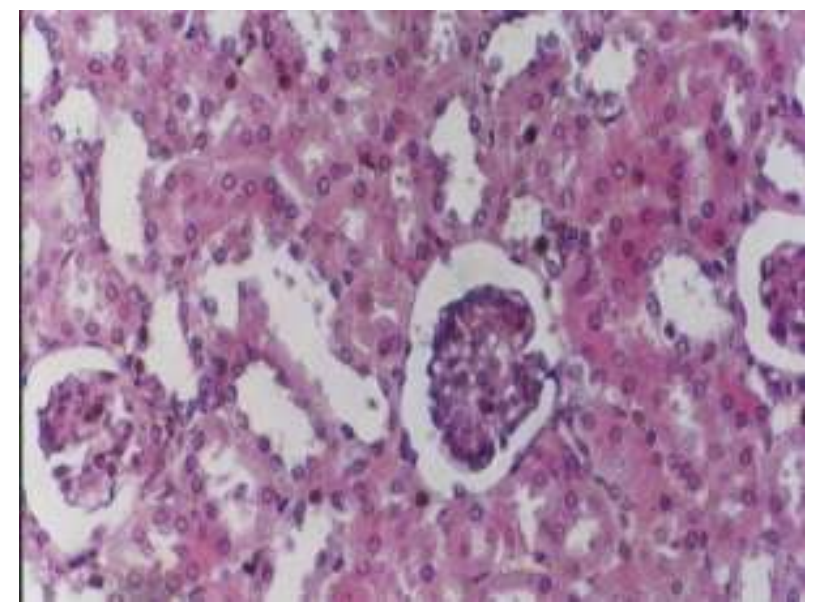

Figure 8: Kidney (toxic dose group), renal cortical area of dilated tubules. (X $100 \mathrm{H} \mathrm{\&} \mathrm{E).}$

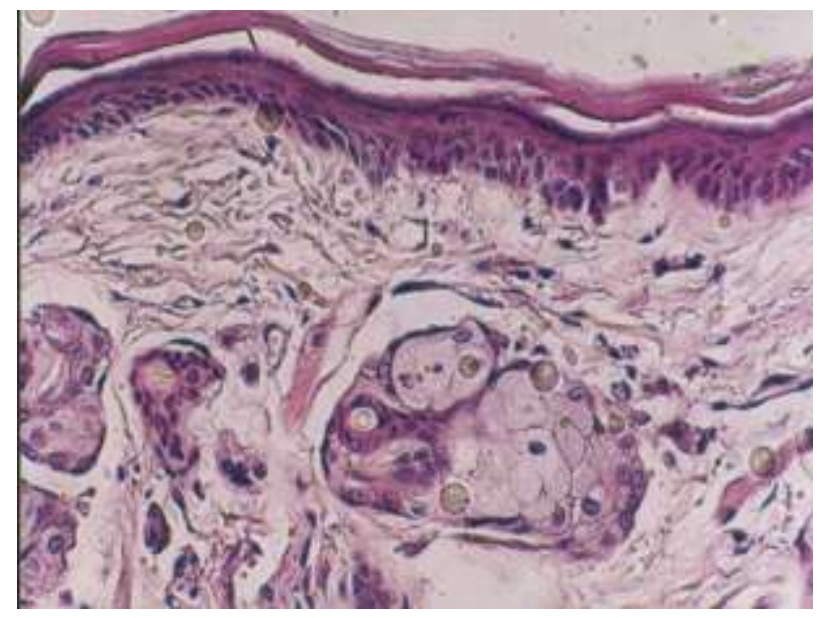

Figure 9: Skin (lips)(toxic dose group), hypertrophy of epidermis and hyperkeratosis. (X 50 H \& E).

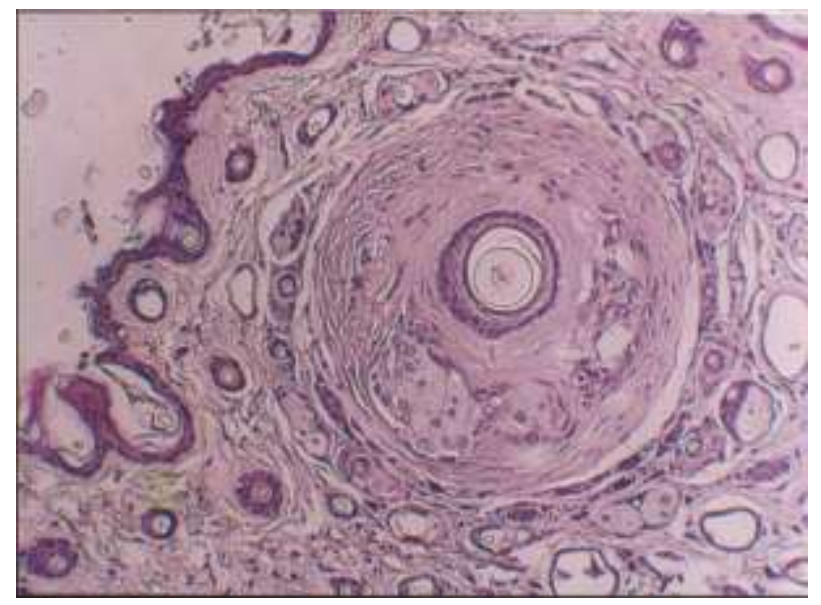

Figure 10: Skin (Lips) (angioedema) (toxic dose group), note dilated hair follicles in dermis(arrow), minimal edema(double arrow), fibrosis(tri_arrow) and thickening of epidermis(oval arrow). (X $100 \mathrm{H} \& \mathrm{E}$ ). 


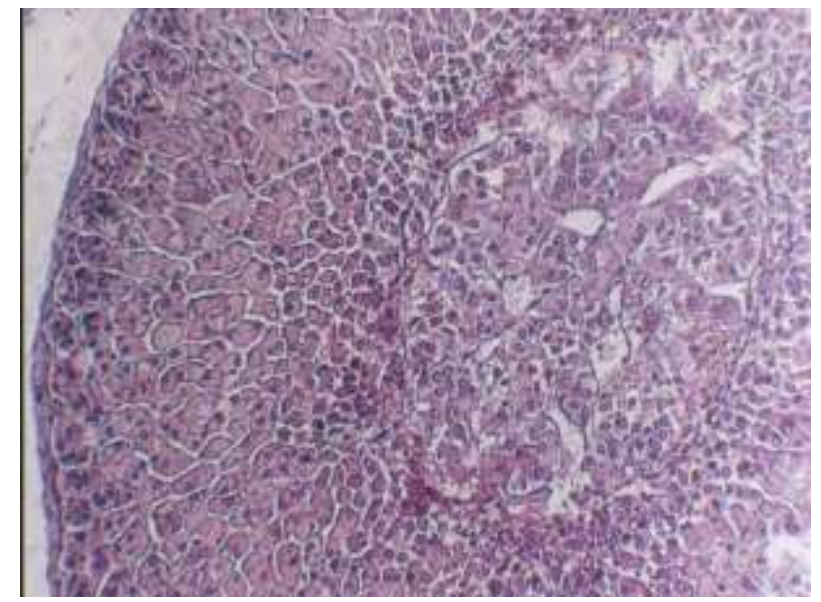

Figure 11: Adrenal gland (toxic dose group), evidence of reduced size of medulla. (X $100 \mathrm{H} \&$ E).

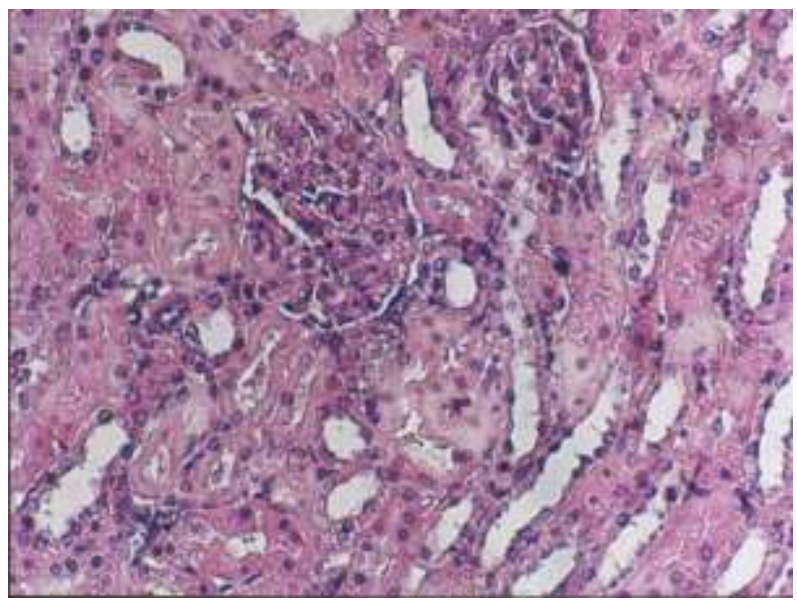

Figure 12: Kidney (extratoxic dose group), areas of dilated renal cortical tubules. (X $50 \mathrm{H} \& \mathrm{E}$ ).

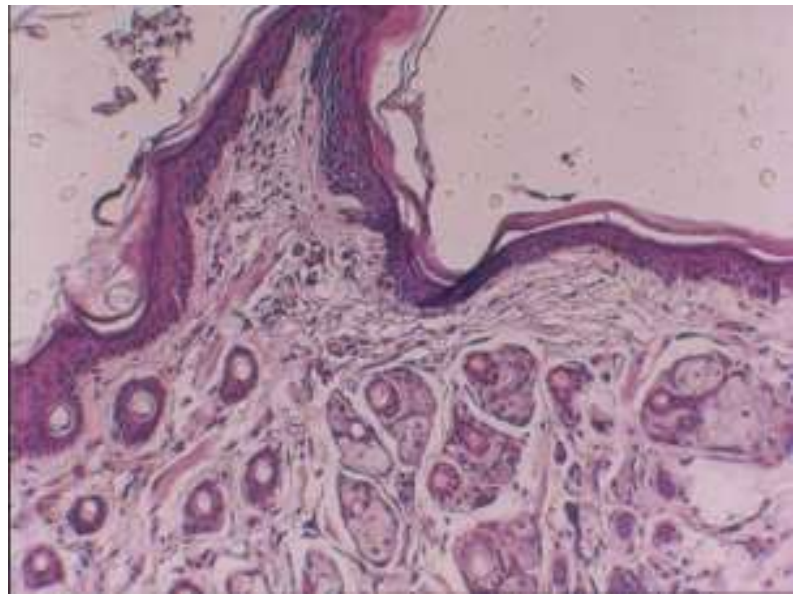

Figure 13: Skin (lips) (extratoxic dose group), an area of hypertrophy(arrow), thickening of epidermis(double arrow) and hyperkeratosis(tri_arrow). (X 100 H \& E). 


\section{References}

1. Pamkoob, R. N. (2004). Managing the client with hypertension. CME Resource. $\quad$ www.netce. $\mathrm{com} /$ conrse. asp? Course $=1012$.

2. Schwartz, G. L. and Scheps, S. G. (2004). Hypertension. ACP Medicine. PP.: 1-16.

3. Goodman, L. S. and Gilman, A. G. (1996). Pharmacological basis of therapeutics. $6^{\text {th }}$ ed. MacGrowHill, New York. PP: 733-781.

4. Rubanyi, G. M. (1993). Brain- Specific Restoration of Angiotensin II corrects Renal Defects seen in Angiotensinogen deficient Mice. J. Cardiovas. Pharmacol. 22: 1-14.

5. Murray, R. K.; Grunner, D. K.; Mayes, P. A. and Rodwell, V. W. (1999). Harper's Biochemistry. Middle East Edition. $25^{\text {th }}$ ed. pp: 552-553.

6. Luna, L.G. (1968). Processing of tissue. Histologic Staining methods of the armed forces institue of pathology. $3^{\text {rd }}$ ed. McGraw-Hill book comp. London, New York, Toronto, Sydney. pp: 12-31.

7. Laurence, D. R. and Bennett, P. N. (1987). Clinical pharmacology $6^{\text {th }}$ ed. pp: 492-493

8. Hashimoto, k.; Imai, K; Yoshimura, S. and Ohtaki, T. (1981). Twelve month studies on the chronic toxicity of captopril in rats. J. Toxicol. Sci. 2: 215-246.

9. Smith, H. A.; Johnes, T. C. and Hunt, R. D. (1972). Veterinary pathology. $4^{\text {th }}$ ed. Lea and Febiger, Philadelphia.

10. Neilson, E. G. (1989). Pathogenesis and therapy of: interstitial nephritis. Kidney Int. 35: $1257-1270$.

11. Guo, X. and Nzerue, C. (2002). How to prevent, recognize, and treat druginduced nephrotoxicity. Clin. J. of Med. 4 (69): 289-312.

12. Takase, K.; Ikuse, T.; Aono, H. and Ohahara, Aristocratic (1995). Toxicity Study of the angiotensin converting enzyme inhibition captopril in rats. Arzneimittel for schung. 45 (1): 15-18.

13. Esther, C. R.; Howard, T. E.; Marino, E. M. Goddard, J. M. and Bernstein, K.E. (1996). Mice lacking angiotensin converting enzyme have low blood pressure, renal pathology, and reduced male fertility. Lab. Invest. 74 (5): 953965.

14. Mazzocchi, G. and Nussdorfer, C. G. (1984). Long term effects of captopril on the morphology of normal rat adrenal zona glomerulosa. Amorphometric Study. Exp. Clin. Endocimal. 84 (2): 148-152.

15. DiNardo, L. J.; Hendrix, R. A.; Anderson, G. and DeDio, R. M. (1990). Angiotensin converting enzyme inhibitor included angioedema of the head and neck. Trans. Pa. Acad. Ophthalmol otolaryngol. 42: 998-1001. 


\section{التغيرات المرضية النسجية في الكليتين واللغدة الكظرية والجلا الناتجة من التاثير السمي للكابتوبريل في الفئران}

$$
\text { كلية الطب البيطري/جامعة ناجي الزيادي }
$$

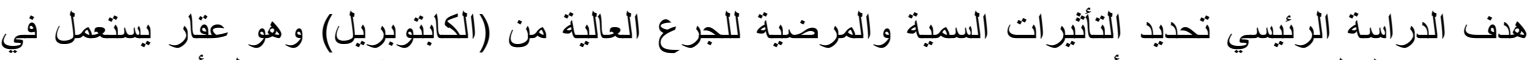

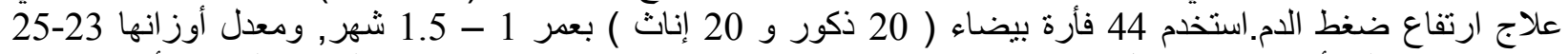

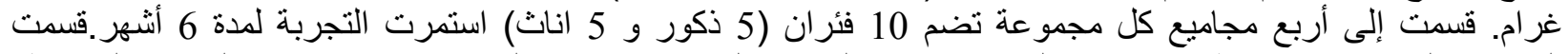

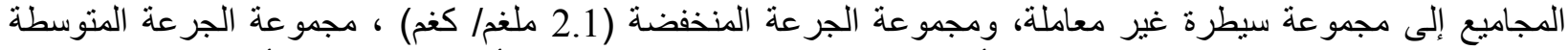

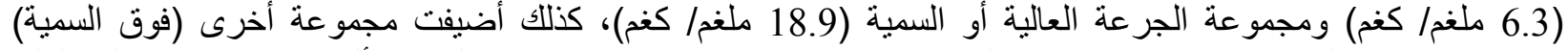
وبجر عة (56.7 ملغم/ كغم) وقد تكونت هذه المجموعة من (2 ذكور و 2 اناث).اظهر الفحص ألمجهري تغيرات على الكئى الكلى

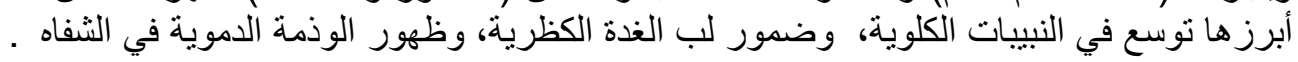

